九州大学学術情報リポジトリ

Kyushu University Institutional Repository

\title{
Biological Monitoring for Detection of Toxic Chemicals in Water by the Swimming Behavior of Small Freshwater Fish
}

\section{Kang, Ik Joon}

Aquatic Biomonitoring and Environmental Laboratory, Department of Bioscience and Biotechnology, Faculty of Agriculture, Kyushu University

Moroishi, Junya

Aquatic Biomonitoring and Environmental Laboratory, Department of Bioscience and Biotechnology, Faculty of Agriculture, Kyushu University

Nakamura, Ayumi

Biomonitoring Group, Seiko Electric Co., Ltd.

Nagafuchi, Ken

Aquatic Biomonitoring and Environmental Laboratory, Department of Bioscience and Biotechnology, Faculty of Agriculture, Kyushu University

他

https://doi.org/10.5109/14062

出版情報：九州大学大学院農学研究院紀要. 54 (1)，pp.209-214，2009-02-27. Faculty of Agriculture, Kyushu University

バージョン：

権利関係: 


\title{
Biological Monitoring for Detection of Toxic Chemicals in Water by the Swimming Behavior of Small Freshwater Fish
}

\section{Ik Joon KANG*, Junya MOROISHI, Ayumi NAKAMURA ${ }^{1}$, Ken NAGAFUCHI, Sang Gyoon KIM ${ }^{1}$ and Yuji OSHIMA ${ }^{2}$}

\author{
Aquatic Biomonitoring and Environmental Laboratory, Department of Bioscience and \\ Biotechnology, Faculty of Agriculture, Kyushu University, \\ Fukuoka 812-8581, Japan \\ (Received November 14, 2008 and accepted December 5, 2008)
}

\begin{abstract}
We conducted exposure tests using three small fish species, medaka (Oryzias latipes), guppy (Poecilia reticulata), and white cloud mountain minnow (Tanichthys albonubes). The fish were exposed to nominal concentrations of test chemicals (potassium cyanide [KCN; 1 and $5 \mathrm{mg} / \mathrm{L}]$, sodium cyanide [NaCN; 1 and $5 \mathrm{mg} / \mathrm{L}]$, and aldicarb [ $5 \mathrm{mg} / \mathrm{L}]$ ) for one hour. We used two cameras for tracking the fish behavior in three dimensional (3D) data. Then the 3D data were analyzed for fish behavior such as, swimming speed and surfacing behavior. Swimming speed and position of the three fish species were affected by KCN, $\mathrm{NaCN}$, and aldicarb exposure test. Three fish species showed the different behavioral patterns after the exposure of test chemicals. Although the patterns of effect on behavioral parameters differed among the test species and toxic chemicals, we could find the significant effects on both the frequency of high swimming speed and duration time of surfacing behavior in test fish. We concluded that three fish species are useful species for monitoring the water quality by their behavioral changes.
\end{abstract}

\section{INTRODUCTION}

There are an increasing number of chemicals used in a wide range of fields, and a concern about the threat of spill accidents caused by toxic chemicals on water system are spread. In fact, spill accidents involving toxic chemicals into aquatic environment were reported around the world. In particular, some reports showed water accidents involving high concentrations of toxic chemicals such as cyanide compounds, phenol, and several pesticides (Capel et al., 1988; Soldán et al., 2001; Yoshida, 2003). These water accidents suggest that monitoring system is required to evaluate water quality at an early stage of toxicant spill on site.

Although chemical analytical instruments are mainly being used in water supplies for monitoring water quality, it is unable to efficiently detect such toxicants in real time. Previous study (Allan et al., 2006) suggested a need of monitoring using aquatic organisms to evaluate water quality in aquatic environment. Until now, several online biomonitoring using aquatic organisms, such like algae, daphnia, bivalve and fish have been already developed and used around the world (Benecke et al., 1982; Sloof et al., 1983; Sluyts et al., 1996; Borcherding and Jantz, 1997; Twist et al., 1997; Naessens and Tran-Minh, 1998; Lechelt et al., 2000; van der Schalie et al., 2001; Borcherding, 2006; Gerhardt et al., 2006).

It is well known that fish are ideal test organism for investigation of behavioral toxicity of chemicals in water (Little and Finger, 1990). Fish exposed to toxic chemicals shows various behavioral alternations, and behavio-

\footnotetext{
Biomonitoring Group, Seiko Electric Co., Ltd.

Laboratory of Marine Environmental Science, Division of Marine Biological Chemistry, Department of Bioscience and Biotechnology, Faculty of Agriculture, Kyushu University

* Corresponding author (E-mail: kangnew@agr.kyushu-u.ac.jp)
}

ral change of fish is effective endpoint for evaluation of changes of water quality by toxicants in a short time of period.

In previous study, we reported the swimming behavioral changes of medaka exposed to toxic chemicals during the short time period of exposure (Kang et al., 2008). In particular, it was demonstrated that the abnormal changes in swimming speed and swimming position were observed in medaka exposed to potassium cyanide, phenol and pesticides during $1 \mathrm{hr}$ exposure test.

In the present study, we chose three small fish species, medaka (Oryzias latipes), guppy (Poecilia reticulata) and white cloud mountain minnow (Tanichthys albonubes) as test organisms. It is easy to maintain and reproduce these fish, and the size of adult fish is small (average length is ca. $3 \mathrm{~cm}$ ). Additionally, there is a lot of toxicological data available from previous many researches (Anderson and Weber, 1975; OECD, 1999; El-Alfy et al., 2001; Ohta et al., 2003; Sarıkaya et al., 2007). We compared their behavioral changes during the $1 \mathrm{hr}$ exposure tests, and potassium cyanide, sodium cyanide and aldicarb were selected as the test chemicals. Three test chemicals are well known to induce neurotoxicity effects on aquatic organisms (Anderson and Weber, 1975; David et al., 2008; Gallo et al., 1995).

\section{MATERIALS AND METHODS}

\section{Test chemicals and test fish}

The test substances, potassium cyanide $(\mathrm{KCN} ;>98 \%$ purity) were purchased from Katayama Chemical Industries Co., Ltd. Sodium cyanide (NaCN; >97\% purity) and aldicarb (>98\% purity) were purchased from Wako Pure Chemical Industries (Osaka, Japan). And, NaCN, $\mathrm{KCN}$, and aldicarb stock solution (100 mg/L) were prepared by dissolving with dechlorinated tap water. Adult medaka (6 months posthatch; mean $\pm \mathrm{SD}$ of body weight 
and total length, $0.6 \pm 0.1 \mathrm{~g}, 39.5 \pm 2.9 \mathrm{~mm}$, respectively) were collected, from broodstock in our laboratory. Guppy (6 months posthatch; mean $\pm \mathrm{SD}$ of body weight and total length, $0.7 \pm 0.3 \mathrm{~g}, 39.9 \pm 3.9 \mathrm{~mm}$, respectively) and white cloud mountain minnow (6 months posthatch; mean $\pm \mathrm{SD}$ of body weight and total length, $0.4 \pm 0.6 \mathrm{~g}$, $33.8 \pm 1.6 \mathrm{~mm}$, respectively) were purchased from a pet shop (Nanpuen, Inc., Fukuoka, Japan).

\section{The exposure test and statistical analysis}

All fish were kept under a photoperiod (14:10-h light:dark) and fed with Artemia nauplii ( $<24 \mathrm{~h}$ after hatching) twice a day. The water temperature was kept at $22 \pm 1{ }^{\circ} \mathrm{C}$, and the dissolved oxygen concentration (mean $\pm \mathrm{SD}$ ) was $7.0 \pm 0.5$. From these fish stocks, 32 medaka and 32 white cloud mountain minnow were selected randomly and used for the exposure test. And, we used 32 only female fish from guppy stock in the exposure test, because the body color and shape of male guppy was not suitable for image recognition, in this study.

The exposure test of this study was conducted as described in previous study (Kang et al., 2008). We exposed the fish to KCN (1 and $5 \mathrm{mg} / \mathrm{L} ; 4$ fish/treatment), $\mathrm{NaCN}$ ( 1 and $5 \mathrm{mg} / \mathrm{L} ; 4$ fish/treatment), and aldicarb ( $5 \mathrm{mg} / \mathrm{L} ; 4$ fish/treatment) for 1 hour. All exposure test were conducted with a continuous flow through system (flow rate; $400 \mathrm{~mm} / \mathrm{sec}$ ). The selected fish were placed into test chamber $(10 \times 10 \times 15 \mathrm{~cm})$, containing $1.8 \mathrm{~L}$ of the test solution. The test solution was delivered to test chamber by a roller pump, Eyela RP-1000 (Tokyo Rikakikai Co., Ltd., Tokyo, Japan). The flow rates of dechlorinated tap water and test solutions were checked by using a graduated cylinder. The renewal time of test solution in test chamber was 20 times once a hour. The behavior of test fish was observed and analyzed by Bio Fish Meter Lab equipment (Seiko Electric Co., Ltd., Fukuoka, Japan). Figure 1 demonstrates the schematic diagram of the exposure test.

The test fish was placed in test chamber and then only dechlorinated water was run through the test chamber for $30 \mathrm{~min}$ for acclimatization. After acclimatization, dechlorinated tap water was run through the test chamber for another $30 \mathrm{~min}$ while we recorded the unexposed behavior of the test fish. Then, the test solution was released into the test chamber for $60 \mathrm{~min}$. The swimming behavior of the test fish was recorded and observed for a total of $90 \mathrm{~min}$, including unexposed period (30 min). The movement of the fish was recorded with the three dimensional data, $x, y$ and $z$ coordinates. From these data, we evaluated the behavior of the fish with swimming speed and position to identify the behavioral changes by the exposure of toxicants in water. All fish were anesthetized in FA-100 solution (dilution, 2000-fold; Tanabe Seiyaku Co. Ltd., Osaka, Japan), drained on filter paper, and measured for body weight and length, after the exposure test.

Our previous study demonstrated that the frequencies of high swimming speed $(150 \leq$ swimming speed $\leq$ $300 \mathrm{~mm} / \mathrm{s}$ ) and duration time of surfacing behavior (the time spent at no more than $20 \mathrm{~mm}$ below the surface) of

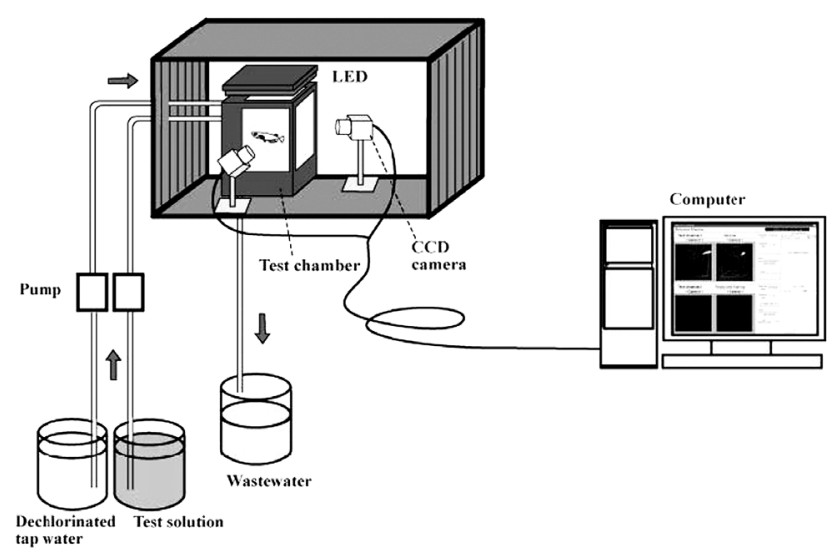

Fig. 1. The diagram of the exposure test.

medaka exposed to several toxicants were remarkably induced, compared to the control (Kang et al., 2008). Therefore, in this study, we evaluated the frequency of high swimming speed in 150 through $300 \mathrm{~mm} / \mathrm{s}$ and the duration time of surfacing behavior. And then the differences of frequencies in high swimming speed and duration time of surfacing behavior were statistically compared between unexposed condition and the exposed conditions.

All data were checked for assumptions of homogeneity of variance across treatments by using Levene's test. Data were analyzed by one-way analysis of variance (ANOVA) and then were tested by using Dunett's test. When no homogeneity was observed, nonparametric statistical comparisons were used to detect differences among treatments (Kruskal-Wallis test). The differences between unexposed and exposed conditions were identified by using individual Mann-Whitney U-tests. A $p$ value of $<0.05$ was considered significant. All statistical analyses were performed by using SPSS Base 10.0J (SPSS Inc., Chicago, IL, USA).

\section{RESULTS AND DISCUSSION}

Two test chemicals, KCN and NaCN affected the swimming speed of test fish, and we found the abnormal increased frequencies of high swimming speed of medaka, guppy and white cloud mountain minnow, in this study. In the guppy exposed to KCN $1 \mathrm{mg} / \mathrm{L}$, an increase in the frequency of high swimming speed was occurred at between 30 and 60 min of the exposure, compared with unexposed conditions (Fig. 2A). However, there was no significant changes in frequencies of high swimming speed in medaka and white cloud mountain minnow exposed to KCN $1 \mathrm{mg} / \mathrm{L}$ for 1 hour.

Furthermore, the frequency of high swimming speed of three test species were increased during the exposure of KCN 5 mg/L (Fig. 2B). There were statistically significant increase in the frequency of high swimming speed in the guppy between 0 and $30 \mathrm{~min}$ of exposure. Exposure to $\mathrm{KCN} 5 \mathrm{mg} / \mathrm{L}$ significantly increased the frequencies in high swimming speed of medaka during 30 to $60 \mathrm{~min}$ of exposure. On the other hand, guppy and white cloud mountain minnow showed decrease of frequency in high 
(A)

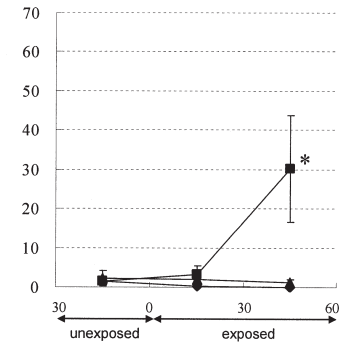

(B)

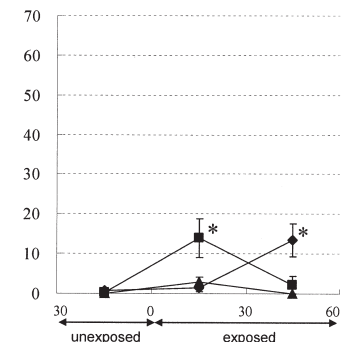

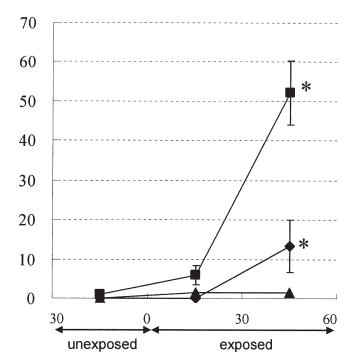

(D)

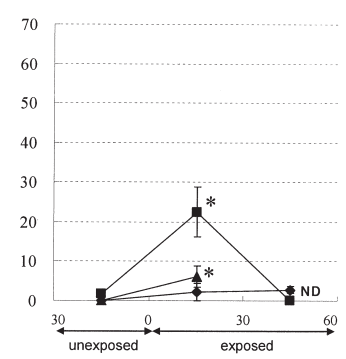

(E)

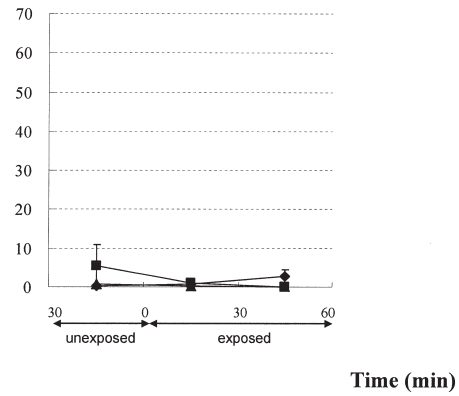

Fig. 2. Frequencies of high swimming speed $(150 \leq$ swimming speed $\leq 300 \mathrm{~mm} / \mathrm{s}$ ) of 3 test species, medaka ( ), guppy $(\square)$, and white cloud mountain minnow $(\boldsymbol{\Delta})$ in the test chemicals treatment group during the behavior test. Total period of experimental duration is $1.5 \mathrm{~h}$ ( $30 \mathrm{~min}$ unexposed [control] condition and 60 min exposed condition). (A): KCN $1 \mathrm{mg} / \mathrm{L}$, (B): KCN $5 \mathrm{mg} / \mathrm{L}$, (C): NaCN $1 \mathrm{mg} / \mathrm{L}$, (D): $\mathrm{NaCN} 5 \mathrm{mg} / \mathrm{L}$, and (E): aldicarb $5 \mathrm{mg} / \mathrm{L}$. Data are shown as mean $\pm \mathrm{SE}(\mathrm{n}=4)$. Statistical significance compared with unexposed condition (*: $p<0.05)$. ND indicates no data during 30 to $60 \mathrm{~min}$ of exposure in the white cloud mountain minnow.

swimming speed during 30 to 60 min of exposure of KCN $5 \mathrm{mg} / \mathrm{L}$.

Similarly, there was a trend toward increased frequencies of high swimming speed in test fish, throughout the NaCN exposure. The NaCN at $1 \mathrm{mg} / \mathrm{L}$ induced an increased frequencies of high swimming speed of medaka and guppy, during 30 to $60 \mathrm{~min}$ of exposure (Fig. 2C). In particular, guppy exposed to $\mathrm{NaCN} 1 \mathrm{mg} / \mathrm{L}$ showed over 5 times more increased frequency of high swimming speed, compared with the unexposed conditions. In contrast, no significant differences in frequencies of high swimming speed in white cloud mountain minnow were found between unexposed and exposed conditions.

Exposure to NaCN $5 \mathrm{mg} / \mathrm{L}$ significantly increased the frequencies of high swimming speed in guppy and white cloud mountain minnow for 0-30 min after the exposure (Fig. 2D). Because all white cloud mountain minnows exposed to $5 \mathrm{mg} / \mathrm{L} \mathrm{NaCN}$ were dead within $60 \mathrm{~min}$ of exposure, the value of swimming performance at between

30 and 60 min of exposure was not able to calculate. In addition, there was no statistical changes in frequency of high swimming speed in medaka.

In the aldicarb exposure $(5 \mathrm{mg} / \mathrm{L})$ test, no changes of frequency in high swimming speed were found in all test species, between unexposed and exposed conditions (Fig. 2E).

Previous study (Iwamatsu, 2006) have reported that the maximum swimming speed of medaka is approximately $300 \mathrm{~mm} / \mathrm{s}$ under normal conditions. And thus we evaluated the frequencies of each swimming speed $(0-300 \mathrm{~mm} / \mathrm{s})$ of medaka exposed to toxic chemicals and found the abnormal increase of their frequency of high swimming speed in fish, in previous study (Kang et al., 2008). In addition, our previous results demonstrated that swimming speeds of $150-300 \mathrm{~mm} / \mathrm{s}$ do not often occur in medaka under unexposed condition and concluded that high swimming speed is an efficient endpoint for the detection of abnormal swimming performance in response to toxins. Several studies also reported that swimming activity of fish was altered by a change of water quality (Smith and Bailey, 1988; Little and Finger, 1990; Cazenave et al., 2008)

The duration time of surfacing behavior were increased in three species exposed to test chemicals. During the KCN $1 \mathrm{mg} / \mathrm{L}$ exposure, swimming area of medaka and guppy were mainly concentrated below the surface water, and their duration time of surfacing behavior were significantly increased between unexposed and exposed conditions (Fig. 3A). The duration of surfacing behavior of medaka was significantly increased for 30-60 min after the KCN $1 \mathrm{mg} / \mathrm{L}$ exposure, and that of guppy was significantly increased for 0-60 min after the KCN $1 \mathrm{mg} / \mathrm{L}$ exposure. In contrast, there was no significant differences in duration time of surfacing behavior in white cloud mountain minnow, between the unexposed and exposed conditions.

Three test species exposed to KCN $5 \mathrm{mg} / \mathrm{L}$ showed a trend toward increase of the duration of surfacing behavior for 0-30 min after the exposure (Fig. 3B), and there was statistical significance in medaka between unexposed and exposed conditions. Throughout the KCN $5 \mathrm{mg} / \mathrm{L}$ exposure, guppy and white cloud mountain minnow also showed the induction of duration time of surfacing behavior, but no significant differences were found between unexposed and exposed conditions.

With $\mathrm{NaCN} 1 \mathrm{mg} / \mathrm{L}$ exposure, a significant increase in the duration time of surfacing behavior was observed in all test species, during the exposed conditions (Fig. $3 \mathrm{C})$.

The duration time of surfacing behavior in white cloud mountain minnow was significantly increased after 0 to $30 \mathrm{~min}$ exposure to $\mathrm{NaCN}$ at $5 \mathrm{mg} / \mathrm{L}$ (Fig. 3D). However, there was no data during the 30-60 min after the exposure, because of the death of all white cloud mountain minnow. Medaka exposed to NaCN $5 \mathrm{mg} / \mathrm{L}$ showed a trend toward increased duration of surfacing behavior, however there was no statistically significant differences between the control and exposed conditions. Moreover, after the exposure to NaCN $5 \mathrm{mg} / \mathrm{L}$, the dura- 

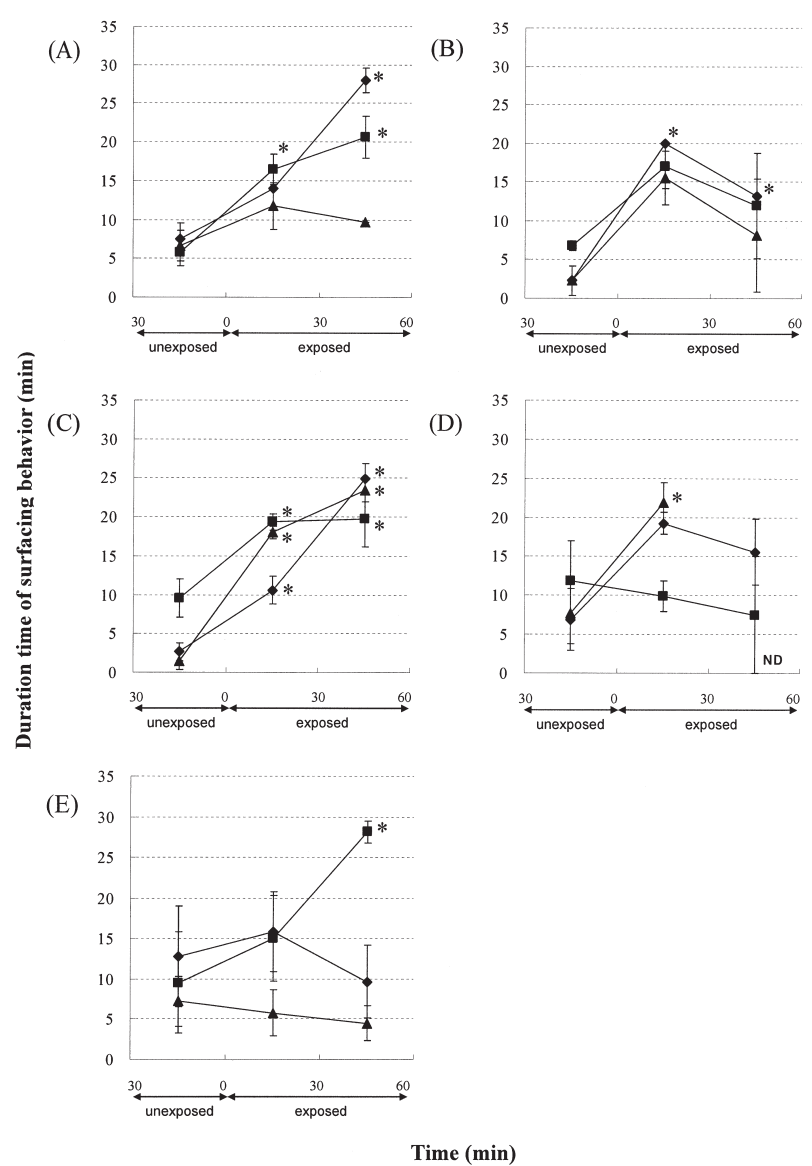

Fig. 3. The duration time of surfacing behavior of 3 test species, medaka ( ), guppy ( $\boldsymbol{\square})$, and white cloud mountain minnow $(\boldsymbol{\Delta})$ exposed to the test chemicals in 0-20 mm Y axis of test chamber during the behavior test. Total period of experimental duration is $1.5 \mathrm{~h}$ (30 min unexposed [control] condition and $60 \mathrm{~min}$ exposed condition). (A): KCN $1 \mathrm{mg} / \mathrm{L}$, (B): KCN $5 \mathrm{mg} / \mathrm{L}$, (C): NaCN $1 \mathrm{mg} / \mathrm{L}$, (D): NaCN $5 \mathrm{mg} / \mathrm{L}$, and (E): aldicarb $5 \mathrm{mg} / \mathrm{L}$. Data are shown as mean $\pm \mathrm{SE}(\mathrm{n}=4)$. Statistical significance compared with unexposed condition $(*: p<0.05)$. ND indicates no data during 30 to 60 min of exposure in the white cloud mountain minnow.

tion time of surfacing behavior in guppy was decreased.

Guppy treated with aldicarb $5 \mathrm{mg} / \mathrm{L}$ showed an increased duration time of surfacing behavior, and we found statistically significant changes in the duration time of surfacing behavior in guppy at between 30 and $60 \mathrm{~min}$ of the exposure, compared with unexposed conditions (Fig. 3E). On the other hand, no statistical significance was observed in the medaka and white cloud mountain minnow exposed to aldicarb $5 \mathrm{mg} / \mathrm{L}$. For 0-30 min after the exposure, the duration time of surfacing behavior in medaka was increased, but there was no statistically significant differences between the unexposed and exposed conditions.

Surfacing behavior is well known to be induced by an exposure to toxicants at high levels (Little and Finger, 1990). However, little studies have demonstrated the abnormality of swimming position in fish exposed to high levels of toxicants. Kang et al. (2008) also reported the concentration of swimming area under the water surface and increased duration time of surfacing behavior in medaka exposed to KCN, phenol and pesticides at high concentrations. Therefore, in the present study, we evaluated the duration time of surfacing behavior (i.e. the time spent at no more than $20 \mathrm{~mm}$ below the surface) and found the abnormal increase of surfacing behavior in fish exposed to test chemicals. From these results, we concluded that increase of duration time of surfacing behavior treated with toxic chemicals is also an efficient endpoint for the detection of abnormal swimming activity in response to toxicants.

Exposure to test chemicals at high levels induced significant changes in the swimming behavior of medaka, guppy and white cloud mountain minnow during the $1-\mathrm{h}$ exposure period, and two kinds of behavioral parameters (frequency of high swimming speed and duration time of surfacing behavior) were affected to varying degrees by $\mathrm{KCN}, \mathrm{NaCN}$, and aldicarb (Table 1). Frequency of high swimming speed of guppy were changed by an exposure to $\mathrm{KCN}$ ( 1 and $5 \mathrm{mg} / \mathrm{L}$ ) and $\mathrm{NaCN}$ (1 and $5 \mathrm{mg} / \mathrm{L}$ ) during the exposure. And significant changes of high swimming speed were observed in medaka exposed to KCN $5 \mathrm{mg} / \mathrm{L}$ and $\mathrm{NaCN} 1 \mathrm{mg} / \mathrm{L}$. Moreover, white cloud mountain minnow showed the increased frequency of high swimming speed in the NaCN $5 \mathrm{mg} / \mathrm{L}$ test. With duration time of surfacing behavior, abnormal increase of it was observed in medaka treated with $\mathrm{KCN}$ and $\mathrm{NaCN}$, and increase in surfacing behavior in white cloud mountain minnow was observed with only $\mathrm{NaCN}$ exposure. On the other hand, we could observe the increase in duration time of surfacing behavior in guppy by an exposure to all test chemicals. From the present results, we concluded that swimming behavioral changes in guppy by an exposure to toxicants is more sensitive than medaka and white cloud mountain minnow, and the sensitivity for test chemicals was guppy $>$ medaka $>$ white cloud mountain minnow on swimming performance. However, we conducted behavioral tests using only three chemicals in this study, and further study will be necessary to evaluate the sensitivity for other kinds of toxic chemicals in small freshwater fish species on behavioral parameters.

The present study demonstrated that high concentrations of toxic chemicals induced abnormal changes of swimming performance in fish in a short time period of the exposure. Although the patterns of effect on behavioral parameters differed among the test species and toxic chemicals, we could find the significant effects on both the frequency of high swimming speed and the duration time of surfacing behavior in three test fish.

\section{ACKNOWLEDGEMENTS}

We would like to thank Yoko Yamasaki for technical help in conducting this study.

\section{REFERENCES}

Allan I. J., B. Vrana, R. Greenwood, G. A. Mills, B. Roig and C. Gonzalez. 2006 A "toolbox" for biological and chemical monitoring requirements for the European Union's Water Framework 
Table 1. The effects of test chemicals on swimming behavior of three test species

\begin{tabular}{cccccccc}
\hline & & \multicolumn{5}{c}{ Test species } \\
\cline { 3 - 7 } & & \multicolumn{2}{c}{ Medaka } & Guppy & $\begin{array}{c}\text { White cloud } \\
\text { mountain minnow }\end{array}$ \\
\cline { 3 - 7 } Test chemicals & Concentrations (mg/L) & Speed & Position & Speed & Position & Speed & Position \\
\hline Potassium cyanide & 1 & - & $*$ & $*$ & $*$ & - & - \\
(KCN) & 5 & $*$ & $*$ & $*$ & - & - & - \\
Sodium cyanide & 1 & $*$ & $*$ & $*$ & $*$ & - & $*$ \\
(NaCN) & 5 & - & - & $*$ & - & $*$ & $*$ \\
Aldicarb & 5 & - & - & - & $*$ & - & - \\
\hline
\end{tabular}

*: indicates significant difference comparing to unexposed conditions $(p<0.05)$.

-: indicates no significant difference comparing to unexposed conditions.

Speed: frequencies of high swimming speed $(150 \leq$ swimming speed $\leq 300 \mathrm{~mm} / \mathrm{s})$ of test fish during the exposure.

Position: the duration time of surfacing behavior of test fish in $0-20 \mathrm{~mm} \mathrm{Y}$ axis of test chamber during the exposure.

Directive. Talanta, 69: 302-322

Anderson P. D. and L. J. Weber. 1975 Toxic Response as a Quantitative Function of Body Size. Toxicol. Appl. Pharmacol., 33: 471-483

Benecke G., W. Falke and C. Schmidt. 1982 Use of algal fluorescence for an automated biological monitoring system. Bull. Environ. Contam. Toxicol., 28: 385-395

Borcherding J. and B. Jantz 1997 Valve movement response of the mussel Dreissena polymorpha - the influence of $\mathrm{pH}$ and turbidity on the acute toxicity of pentachlorophenol under laboratory and field conditions. Ecotoxicol, 6: 153-165

Borcherding J. 2006 Ten years of practical experience with the Dreissena-Monitor, a biological early warning system for continuous water quality monitoring Hydrobiologia, 556: 417-426

Capel P. D., W. Giger, P. Reichert and O. Wanner 1988 Accidental input of pesticides into the Rhine River. Environ. Sci. Technol., 22: 992-997

Cazenave J., M. L. Nores, M. Miceli, M. P. Díaz, D. A. Wunderlin and M. A. Bistoni 2008 Changes in the swimming activity and the glutathione S-transferase activity of Jenynsia multidentata fed with microcystin-RR. Water Res., 42: 1299-1307

David M., V. Munaswamy, R. Halappa and S. R. Marigoudar 2008 Impact of sodium cyanide on catalase activity in the freshwater exotic carp, Cyprinus carpio (Linnaeus). Pestic. Biochem. Physiol., 92: 15-18

El-Alfy A. T., S. Grisle and D. Schlenk 2001 Characterization of salinity-enhanced toxicity of aldicarb to Japanese medaka: Sexual and Developmental Differences. Environ. Toxicol. Chem., 20: 2093-2098

Gallo D., A. Merendino, J. Keizer and L. Vittozzi 1995 Acute toxicity of two carbamates to the guppy (Poecilia reticulata) and the zebrafish (Brachydanio rerio). Sci.Total Environ., 171: $131-136$

Gerhardt A., M. K. Ingram, I. J. Kang and S. Ulitzur 2006 In situ on-line toxicity biomonitoring in water: Recent developments. Environ. Toxicol. Chem., 25: 2263-2271

Iwamatsu T. 2006 The integrated book for the biology of the medaka. Daigaku-kyoiku-shuppan. Okayama, Japan (in Japanese). pp. 402-410

Kang I. J., J. Moroishi, M. Yamasuga, S. G. Kim and Y. Oshima 2008 A study on swimming behavioral toxicity of Japanese medaka (Oryzias latipes) exposed to various chemicals for biological monitoring of water quality. In "Atmospheric and Biological Environmental Monitoring”, Kim Y. J., U. Platt, M. B. Gu and H. Iwahashi, Springer, Berlin, (in press)

Lechelt M., W. Blohm, B. Kirschneit, M. Pfeiffer, E. Gresens, J. Liley, R. Holz, C. Lüring and C. Moldaenke 2000 Monitoring of surface water by ultrasensitive Daphnia Toximeter. Environ. Toxicol., 15: 390-400
Little E. E., and S. E. Finger 1990 Swimming behavior as an indicator of sublethal toxicity in fish. Environ. Toxicol. Chem., $\mathbf{9}$ $13-19$

Naessens M. and C. Tran-Minh 1998 Whole-cell biosensor for direct determination of solvent vapours. Biosens. Bioelectron., 13: $341-346$

Nimkerdphol K. and M. Nakagawa 2008 Effect of sodium hypochlorite on zebrafish swimming behavior estimated by fractal dimension analysis. J. Biosci. Bioengineer., 105: 486-492

Ohta N., M. Aizu, T. Kaneko, T. Sato and H. Kobayashi 2003 Damage to the gills, skin and other tissues by lysenin and the coelomic fluid of the earthworm Eisenia foetida in two teleosts, Tanichthys albonubes and Oreochromis mossambicus. J. Exp. Zool., 295A : 117-126

Organization for Economic Cooperation and Development 1999 Final report from the OECD expert consultation meeting. London, UK, 28-29 October 1998. Report 9906. Environmental Health and Safety Division, Paris, France

Sarıkaya R., M. Selvi, O. Koçak and F. Erkoç 2007 Investigation of acute toxicity of fenitrothion on guppies Poecilia reticulate. J. Appl. Toxicol., 27: 318-321

Sismeiro-Vivas J., N. Abrantes, J. L. Pereira, B. B. Castro. and F. Gonçalves 2007 Short-term effects of Quirlan ${ }^{\circledR}$ (chlorfenvinphos) on the behavior and acetylcholinesterase activity of Gambusia holbrooki. Environ. Toxicol., 22: 194-202

Sloof W., D. de Zwart and J. M. Marquenie 1983 Detection limits of a biological monitoring system for chemical water pollution based on mussel activity. Bull. Environ. Contam. Toxicol. 30: $400-405$

Sluyts H., F. van Hoof, A. Cornet and J. Paulussen 1996 A dynamic new alarm system for use in biological early warning systems. Environ. Toxicol. Chem., 15: 1317-1323

Smith E. H. and H. C. Bailey 1988 Development of a system for continuous biomonitoring of a domestic water source for early warning of contaminants. In "Automated biomonitoring: living sensors as environmental monitors", ed. by D. S. Gruber and J. M. Diamond, Ellis Horwood, Chichester, U. K., pp. 182-205

Soldán P., M. Pavonič, J. Bouček and J. Kokeš. 2001 Baia Mare accident-Brief ecotoxicological report of Czech experts. Ecotoxicol. Environ. Saf., 49: 255-261

Tsuda T., Kojima M., Harada H., Nakajima A., Aoki S. 1997 Acute toxicity, accumulation and excertion of organophosphorous insecticides and their oxidation products in killifish. Chemosphere, 35: 939-949

Twist H., A. C. Edwards and G. A. Codd 1997 A novel in-situ biomonitor using alginate immobilized algae (Scenedesmus subspicatus) for the assessment of eutrophication in flowing surface waters. Water Res., 31: 2066-2072

van der Schalie W. H., T. R. Shedd, P. L. Knechtges and M. W. 
Widder 2001 Using higher organisms in biological early warning systems for real-time toxicity detection. Biosens. Bioelectron., 16: $457-465$
Yoshida F. 2003 IT pollution problems in Asia. Econ. J. Hakkaido. Univ., 32: 1-23 